\title{
4G C-Shaped compact microstrip antenna design and production
}

\section{G C-Şeklinde açıklıklı kompakt mikroşerit anten tasarımı ve ürretimi}

\author{
Ahmet Hayrettin YÜZER ${ }^{*}$, Cihat ŞEKER ${ }^{2}$ \\ 1Department of Electric-Electronics Engineering, Engineering Faculty, Karabuk University, Karabuk, Turkey. \\ hayrettinyuzer@karabuk.edu.tr \\ 2Department of Medical Engineering, Engineering Faculty, Karabuk University, Karabuk, Turkey. \\ cihatseker@karabuk.edu.tr
}

Received/Geliş Tarihi: 05.04.2016, Accepted/Kabul Tarihi: 17.02.2017

* Corresponding author/Yazıșlan Yazar

doi: $10.5505 /$ pajes.2017.27880

Research Article/Araștırma Makalesi

\section{Abstract}

In this paper, an application for a monopole antenna which complies with worldwide interoperability for microwave access (WiMAX) is presented. The proposed antenna operates in the frequency range of 3.43-3.61 GHz applicable for WiMAX. The antenna is fabricated on FR4 plate of $33.25 \times 33.25 \times 1.6 \mathrm{~mm}^{3}$. The performance of the antenna is analyzed in terms of radiation pattern, gain and s-parameters. The s-parameter of the antenna are verified through measurements. The obtained results illustrate that the presented antenna has better characteristics in terms of operating band as well as return loss as compared to the antennas previously published in the literature.

Keywords: WiMAX, Monopole antenna, C-shape antenna, 4G antenna
Öz

Bu calıșmada, mikrodalga erișim için dünya capında birlikte çalışlabilirlik (WiMAX) uygulamasina uyumlu bir monopol anten sunulmustur. Önerilen anten WiMAX'e uygun olan 3.43-3.61 GHz frekans aralı̆ı̆ında çalışmaktadır. Anten, FR4 plaka üzerinde 33.25 × $33.25 \times 1.6$ mm$^{3}$ boyutlarında üretilmiștir. Anten kazanç, ıșıma paterni ve s parametreleri açısından analiz edilmiștir. $S$ parametreleri yapılan ölçüm sonuçları ile doğrulanmıștır. Elde edilen sonuçlar göstermistir ki sunulan antenin önceden literatürde yayınlanan antenlere kıyasla çalışma bandı ve geri dönüş kaybı gibi anten karakteristikleri daha iyidir.

Anahtar kelimeler: WiMAX, Monopol anten, C-sekilli anten, 4G anten

\section{Introduction}

With the development of technology, communication devices need the antenna that operates in a multi-band manner. Therefore, the basic aim of the antenna designers is to develop an antenna that integrates different wireless communication applications operating at different frequency bands. The applications such as UMTS (Universal Mobile Telecommunications System) and WiMAX (Worldwide Interoperability for Microwave Access) have been widely used in wireless communication. Standards for WIMAX networks are defined by IEEE 802.16 Broadband Wireless Access Working Group [1]. In order to meet the requirements of such broadband operations as well as size reduction, the microstrip antennas, particularly the compact microstrip antennas, have been preferred because of their various advantages such as good radiation pattern, low cost, small size, easy fabrication and integrability with microwave devices. [2]. The traditional microstrip antennas commonly gives narrow bandwidth and work in single band [3]. After some modification these antennas have been designed to work in multiple frequencies. Several techniques such as changing the distance between ground plane and patch [4], connecting variable inductive loads or capacitive loads to the patch [5], making slots of different shapes on the radiating patch [6]-[8], stub loading technique [9], loading with shorting walls [10],[11] are applicable to design the antenna for multiple band. The basic slot monopole antenna is an antenna having linear slot [12],[13]. This antenna makes easier to adjust the resonance frequency by varying the length of slot.

Huynh and Lee [14] improved the slot antenna in 1995 as a single-patch, single-layer wideband antenna having linear polarization. Lee et al. antennas are followed by lots of studies. The studies published recently indicate that the U-shaped slotted patch antenna can be designed both for dual-band applications and for wideband applications [15],[16].

The antennas given above were designed by either adding a single or more shorting walls to the antenna or by modifying the shape of antenna in order to design it for single-band and multi-bands. Characteristics of the tri-band U-shaped microstrip patch antenna having complicated design has been verified by published papers [17].

This study presents the result of the design, optimization and production of a slot loaded C-shaped antenna working at single frequency band of $3.5 \mathrm{GHz}$. The proposed antenna is composed of single C-shaped slot loading. The operating band is tuned by varying the lengths of patch. An extensive parametric study is made to grasp the effects of varying size of the patch over return loss by using Ansoft HFSS software. In addition to the study characteristics of antenna including peak gain and radiation patterns are investigated and analyzed.

\section{Antenna configuration and measurements}

The proposed antenna is designed on FR-4 substrate $\left(\epsilon_{r}\right.$ is 4.4 and loss tangent is 0.02 ) height of substrate $h=1.6 \mathrm{~mm}$. The antenna coordinate drawing on rectangular coordinate system (RCS) is given in Figure 1(a). The origin of the RCS is positioned approximately in the middle of the c-shaped patch. The designed C-shaped antenna is fed via sma connector at the point represent as $C(-14 \mathrm{~mm})$ as shown in Figure 1(a). The designed antenna has one vertical slot of dimensions $8 \times$ $8 \mathrm{~mm}^{2}$ and one-cylinder slot having dimensions ( $5 \mathrm{~mm}$ radius and $0.1 \mathrm{~mm}$ height) as shown in Figure 1(a).

Geometry and dimension of the antenna and the photo of the fabricated antenna are given in Figure 1. The ground plane dimensions are $33.25 \mathrm{~mm} \times 20.25 \mathrm{~mm} \times 0.1 \mathrm{~mm}$ and total 
antenna dimensions are $33.25 \mathrm{~mm} \times 33.25 \mathrm{~mm} \times 1.5 \mathrm{~mm}$ for the proposed antenna.
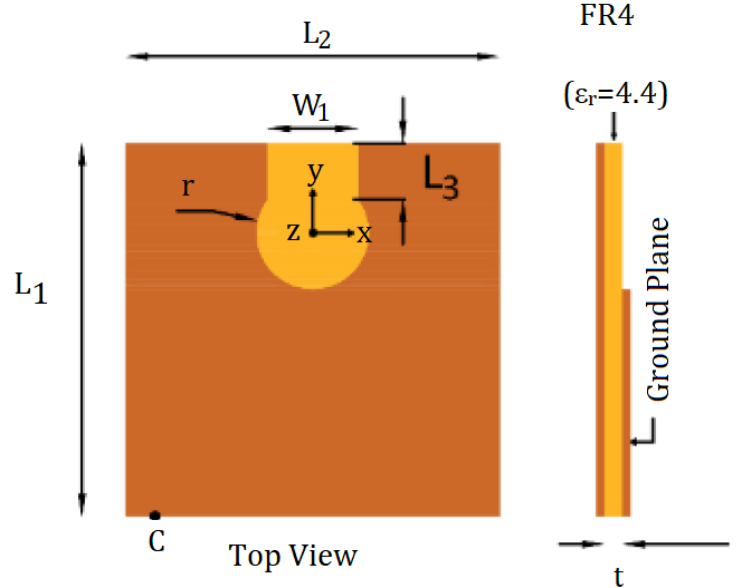

Side View

(a)

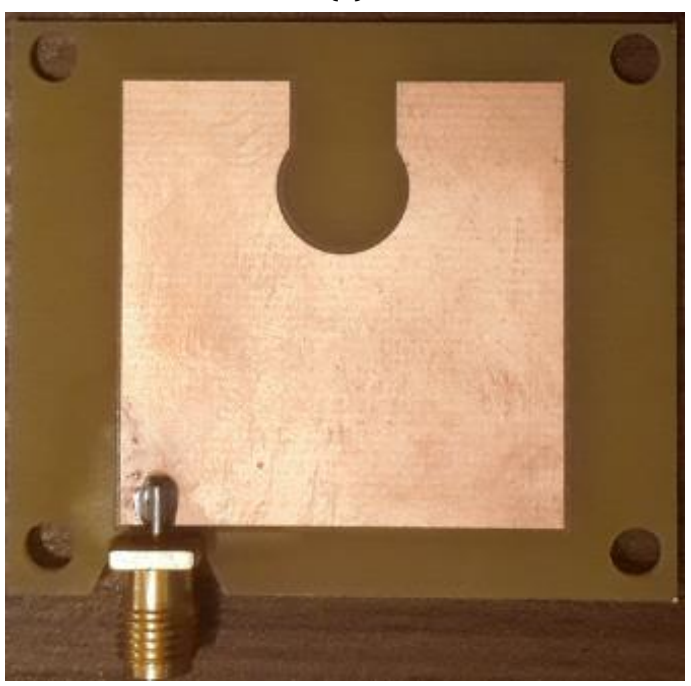

(b): Top view of the fabricated antenna.

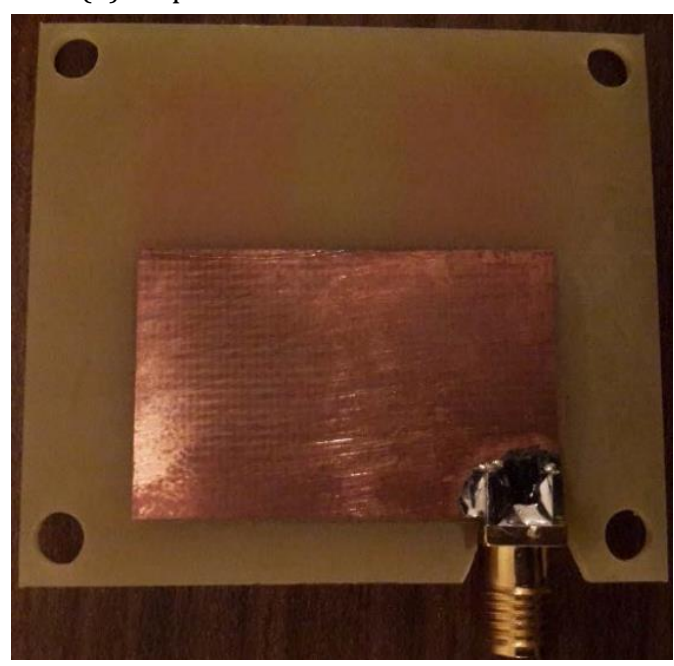

(c): Bottom view of the fabricated antenna.

Figure 1: Configuration of proposed $3.5 \mathrm{GHz}$ C-shape slot loaded antenna.
Antenna matching measurements (S11 measurement) are done with HEWLETT PACKARD 8720D Network Analyzer instrument, after calibration process is performed with using Agilent Standard components. Photograph of the measurement setup is given in Figure 2.

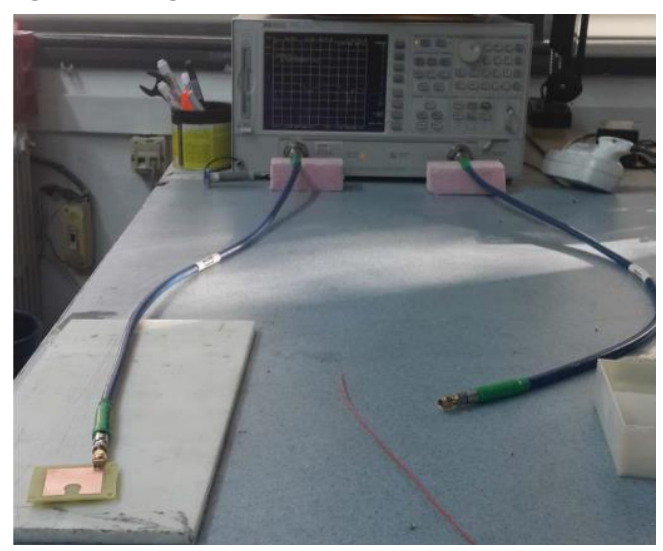

Figure 2: Photograph of the measurement setup.

\section{Results and discussion}

Three dimensional finite element analysis (FEA) models are developed in HFSS for proposed antenna. The parametric study results show a satisfactory convergence with the experimental results as discussed below.

\subsection{Parametric study}

The effect of the all of parameters are investigated on the performance of the antennas. " $L_{1}$ " and " $L_{2}$ " are main parameters of lengths that change the performance significantly. Resonance frequency and bandwidth changes are checked by parametric study. In this study, all of parameters have been optimized with simulation.

\subsubsection{Effect of changing the lengths of patch $\left(L_{1}, L_{2}\right)$}

The fluctuation in the return loss with respect to frequency is given in Figure 3. The figure given below shows the fluctuation in the return loss vs. frequency by taking the lengths " $L_{1}$ ", " $L_{2}$ " of patch as variables. In this study, all other variables were kept constant and $L_{1}=L_{2}$ situation is considered. When $L_{1}=L_{2}=28.25 \mathrm{~mm}$ it was observed that center frequency is shifted approximately $900 \mathrm{MHz}$ to left. When $L_{1}=L_{2}=$ $28.25 \mathrm{~mm}$ it was realized that center frequency is shifted approximately $335 \mathrm{MHz}$ to right. When $L_{1}=L_{2}=33.25 \mathrm{~mm}$ it was observed that the return loss greater than the value it has been shifted from the center frequency.

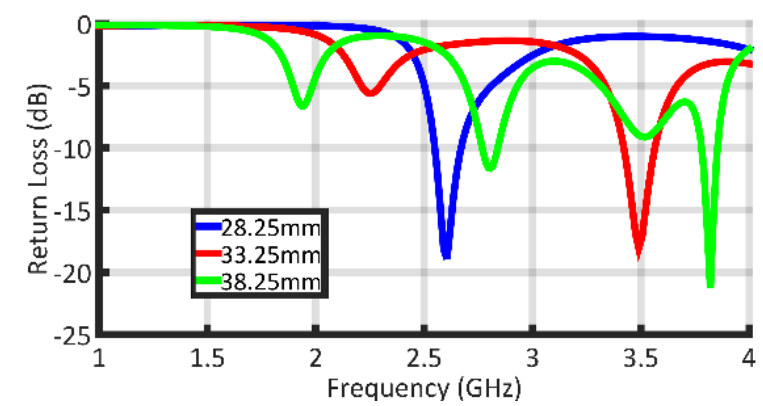

Figure 3: Effect of variation in the patch length $L_{1}, L_{2}$

(Taking all other parameters were constant). Frequency versus fluctuation in return loss of the antenna by taking the lengths " $L_{1}$ ", " $L_{2}$ " as variables for proposed antenna. 


\subsubsection{Peak gain}

The gain of the antenna vs. frequency in the considered operating band is as shown in the Figure 4. Maximum value of the gain is approximately $4.60 \mathrm{~dB}$ at $3.5 \mathrm{GHz}$.

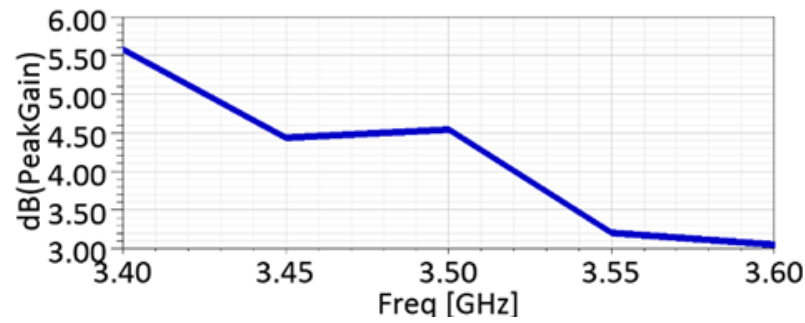

Figure 4: Simulation peak gain of the proposed antenna.

\subsection{Optimized results}

\subsubsection{Return loss}

After excuting the parametric study, the proposed antenna design has been optimized and improved with Ansoft HFSS software. Bandwidth and the return loss characteristics were optimized in the desired bands when the patch lengths are $33.25 \mathrm{~mm}, 33.25 \mathrm{~mm}$. The dimensions of proposed antenna are given in Table 1.

Table 1: Optimized 3.5 GHz C-shaped compact microstrip antenna elements dimensions.

\begin{tabular}{lcc}
\hline \multicolumn{1}{c}{ Parameters } & Symbols & Dimensions $(\mathrm{mm})$ \\
\hline Patch width & $L_{1}$ & 33.25 \\
Patch length & $L_{2}$ & 33.25 \\
Vertical slot length & $L_{3}$ & 5 \\
Horizontal slot width & $W_{1}$ & 8 \\
Radius of cylinder slot & $r$ & 5 \\
Feed position & $C$ & -14 \\
Substrate thickness & $t$ & 1.6 \\
\hline
\end{tabular}

The return loss of the antenna is lower than $10 \mathrm{~dB}$ at frequencies of $3.5 \mathrm{GHz}$ as shown in Figure 5, this shows that this antenna can be operate in $4 \mathrm{G}$. The corresponding bandwidth is found to be $5.14 \%$.

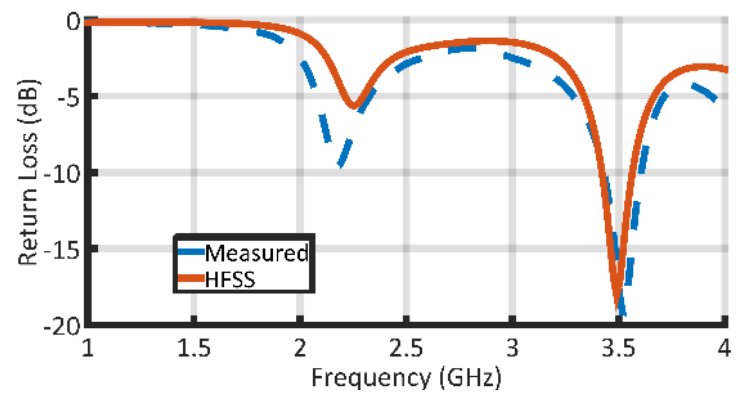

Figure 5: Simulation and measurement return loss of the proposed antenna with respect to frequency after optimization.

\subsubsection{Voltage standing wave ratio (VSWR)}

VSWR graph of the designed antenna is given in Figure 6. By looking the figure especially for $3.5 \mathrm{GHz}$, It can be said that VSWR result is very good (approx. VSWR is 2.34) Acceptable region for the VSWR value is between 2 and 2.5 for the antenna having lengths of patch $33.25 \mathrm{~mm}$.

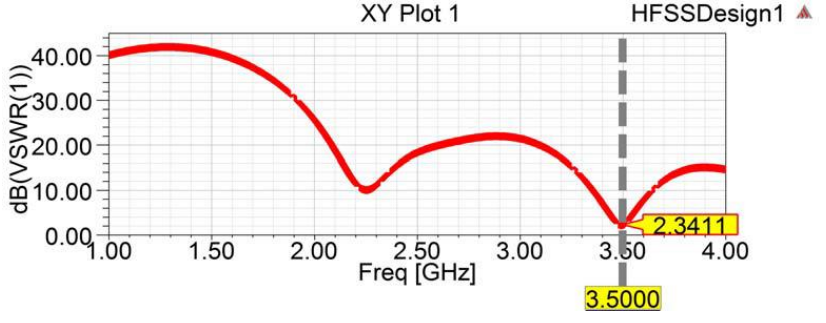

Figure 6: Simulation result (VSWR) of the proposed antenna.

\subsubsection{D Radiation patterns}

The radiation patterns of the designed C-shaped microstrip patch having circular slot antenna at the afore-mentioned band of three different resonance frequencies are as shown in Figure 7.
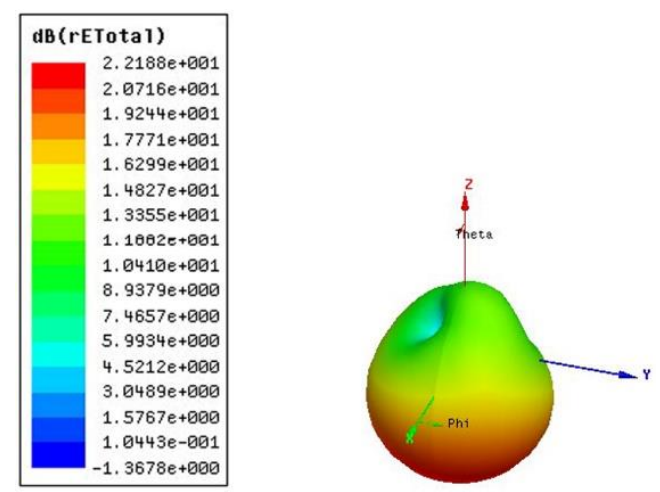

(a): $3.45 \mathrm{GHz}$.

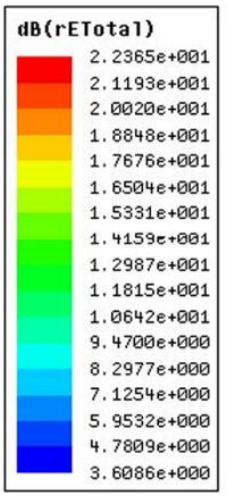

(b): $3.50 \mathrm{GHz}$.
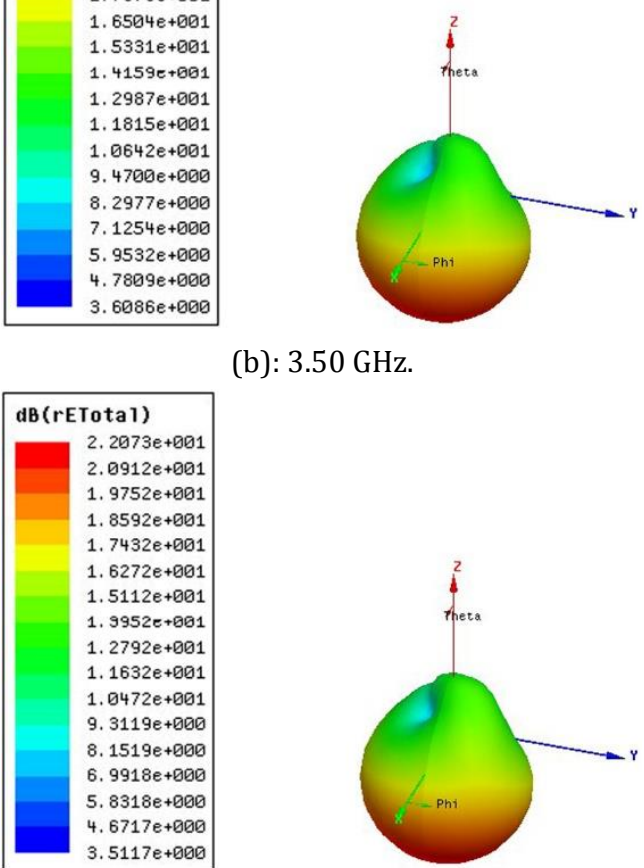

(1)

$$
01
$$$$
1
$$$$
1
$$$$
\text { | }
$$

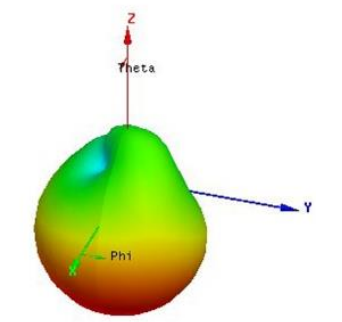

(c): $3.55 \mathrm{GHz}$.

Figure 7: Radiation patterns simulation results of the proposed antenna for $3.45 \mathrm{GHz}$. (a): $3.50 \mathrm{GHz}$, (b) and,

(c): $3.55 \mathrm{GHz}$. 


\section{Conclusion}

Although it numerous times it has been reported that patch antenna has narrow bandwidth, in this study an antenna with a wider bandwidth than regular patch antenna has been designed for $4 \mathrm{G}$ systems. In order to widen the antenna bandwidth a circular type slot is added. Afterwards the antenna has been fabricated and return loss is measured as well as simulated in HFSS. Simulation results indicate that the 3D radiation patterns in the $3.45-3.55 \mathrm{GHz}$ range are acceptable, thus covering the band specified for $4 \mathrm{G}$ (WiMAX). Good gain figure of the antenna is reported in the paper.

\section{References}

[1] IEEE Standard for Worldwide Interoperability for Microwave Access. "IEEE 802.16m System Requirements". http://ieee802.org/16/tgm/docs/80216m-07_002r7.pdf (04.04.2016)

[2] Balanis CA. Antenna Theory: Analysis and Design. $3^{\text {rd }}$ ed. New York, NY, USA, Wiley, 1997.

[3] Luk KM, Mak CL, Chow YL, Lee KF. "Broadband microstrip patch antenna”. Electronics Letters, 34(15), 1442-1443, 1998.

[4] James JR, Hall PS. Handbook of Microstrip Antennas. $1^{\text {st }}$ ed. London, England, Short Run Press Ltd, 1989.

[5] Kumar G, Ray KP. Broadband Microstrip Antennas. $1^{\text {st }}$ ed. Boston, London, Artech House, 2003.

[6] Bao XL, Ammann MJ. "Microstrip-fed dual frequency annular-Slot antenna loaded by split-ring-slot". IET Microwave Antennas Propagation, 3(5), 757-764, 2009.

[7] Sim CYD, Row JS, Chen SH. "A dual-band antenna design for GPS and UMTS applications". Microwave and Optical Technology Letters, 49(8), 1935-1939, 2007.
[8] Liu CP, Wu JK, Liu JC. "Modified stacked inverted-F antenna with corner truncated techniques for WLAN $2.4 / 5 \mathrm{GHz}$ band applications". Microwave and Optical Technology Letters, 48(12), 2378-2381, 2006.

[9] Ray KP, Kumar G. "Tunable and dual band circular microstrip antenna with stubs". IEEE Transactions on Antennas and Propagation, 48(7), 1036-1039, 2000.

[10] Ollikainen J, Fischer M, Vainikainen P. "Thin dual resonant stacked shorted patch antenna for mobile communications". Electronics Letters, 35(6), 437-439, 1999.

[11] Himdi, M, Daniel JP. "Analysis of printed linear slot antenna using lossy transmission line model". Electronics Letters, 28(6), 598-601, 1992.

[12] Kim IK, Kidera N, Pinel S, Papapolymerou J, Laskar J, Yook JG, Tentzeris MM. "Linear tapered cavity-backed slot antenna for millimeter-wave LTCC modules". IEEE Antennas and Wireless Propagation Letters, 5(1), 175-178, 2006.

[13] Mishra A, Singh P, Yadav NP, Ansari JA, Vishvakarma BR. "Compact shorted microstrip patch antenna for dual band operation". Progress in Electromagnetics Research C, 9, 171-182, 2009.

[14] Huynh T, Lee KF. "Single-Layer single-patch wideband microstrip antenna". Electronics Letters, 31(16), 1310-1312, 1995.

[15] Guo YX, Luk KM, Lee KF, Chow YL. "Double V-Slot rectangular patch antenna". Electronics Letters, 34, 1805-1806, 1998.

[16] Lee KF, Yang SLS, Kishk AA. "Dual and multi band u-slot patch antennas". IEEE Antennas and Wireless Propagation Letters, 7, 645-647, 2008.

[17] Tarboush HFA, Nilavalan R, Budimir D, Al-Raweshidy HS. "Double u-slots patch antenna for tri-band wireless systems". International Journal RF and Microwave Computer-Aided Engineering, 20(3), 279-285, 2010. 